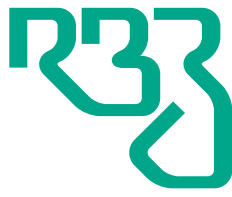

Brasileira de Zootecnia

Brazilian Journal of Animal Science ISSN 1806-9290

www.rbz.org.br

\section{Effects of adding dried distillers grains with solubles (DDGS) to dog diets supplemented with xylanase and protease}

\author{
Larissa Wünsche Risolia $^{1}$ (iD), Tabyta Tamara Sabchuk ${ }^{1}$ (iD), Fabiane Yukiko \\ Murakami $^{1}$ (iD), Ananda Portella Félix ${ }^{1}$ (iD), Alex Maiorka ${ }^{1}$ (iD, Simone \\ Gisele de Oliveira $^{1^{*}}$ iD \\ ${ }^{1}$ Universidade Federal do Paraná, Departamento de Zootecnia, Curitiba, PR, Brasil.
}

*Corresponding author:

sgoliveira@ufpr.br

Received: June 4, 2019

Accepted: August 6, 2019

How to cite: Risolia, L. W.; Sabchuk, T. T.

Murakami, F. Y.; Félix, A. P.; Maiorka, A. and Oliveira, S. G. 2019. Effects of adding dried distillers grains with solubles (DDGS) to dog diets supplemented with xylanase and protease. Revista Brasileira de Zootecnia 48:e20190112. https://doi.org/10.1590/rbz4820190112

Copyright: This is an open access article distributed under the terms of the

Creative Commons Attribution License (http://creativecommons.org/licenses/by/4.0/) which permits unrestricted use, distribution, and reproduction in any medium, provided the original work is properly cited.
ABSTRACT - This study aimed to evaluate the effects of including $200 \mathrm{~g} \mathrm{~kg}^{-1}$ dried distillers grains with solubles (DDGS) to xylanase- and protease-supplemented diets for dogs on kibble properties, digestibility, fecal characteristics, and palatability. Experimental diets consisted of: $0 \mathrm{~g} \mathrm{~kg}^{-1}$ DDGS without enzymes (0WE), $0 \mathrm{~g} \mathrm{~kg}^{-1}$ DDGS with xylanase and protease (OXP), $200 \mathrm{~g} \mathrm{~kg}^{-1}$ DDGS without enzymes (200WE), $200 \mathrm{~g} \mathrm{~kg}^{-1}$ DDGS with xylanase (200X), $200 \mathrm{~g} \mathrm{~kg}^{-1}$ DDGS with protease (200P), and $200 \mathrm{~g} \mathrm{~kg}^{-1}$ DDGS with xylanase and protease (200XP). Kibbles were evaluated for density, extruded size, expansion index, hardness, and uniformity. Six beagle dogs were distributed in a $6 \times 6$ Latin square design for analysis of digestibility and fecal characteristics. A palatability assay was also conducted in 16 beagle dogs, comparing the following treatment groups: OWE vs. 200WE and 0XP vs. 200XP. The results showed that DDGS inclusion had no influence on kibble physical properties and reduced digestibility of dry matter (DM), ether extract after acid hydrolysis, gross energy, and organic matter, regardless of enzyme addition. Moreover, dietary addition of DDGS reduced fecal $\mathrm{pH}$ and increased total short-chain fatty acid, acetate, and propionate productions. Fecal odor was increased in dogs fed diets containing DDGS. Regarding palatability, animals preferred diets supplemented with enzymes and without DDGS, and no difference was observed when comparing OWE and 200WE diets. No changes in the physical properties of kibbles were caused by DDGS inclusion; therefore, it can be used in diet formulation without interfering with the industrial process. Increased production of SCFA and a possible modulation of digestive tract microbiota promoted by DDGS addition may benefit animals. However, at the tested levels, enzymes had no positive effects on diet digestibility. Despite reducing digestibility, DDGS can still be included without enzyme supplementation in low-cost diets for dogs, as nutrient digestibility of the diet remains within acceptable limits for some pet food categories.

Keywords: digestibility, enzymes, fecal characteristics, palatability, short-chain fatty acids

\title{
Introduction
}

Given the growth of the dog food market over the years, and its high competitiveness, new ingredients have been increasingly sought to reduce formulation costs without interfering with diet quality. Industrial co-products have stood out in pet nutrition lately. In this context, dried distillers grains with solubles (DDGS), which derive from grain fermentation for ethanol production, could possibly be used in the pet food industry. 
Dried distillers grains with solubles have a potential to be included in diets for animal nutrition purposes since they have higher concentrations of protein, fat, vitamins, and minerals compared with corn meals (Spiehs et al., 2002; Widyaratne and Zijlstra, 2007). However, their use in monogastric feeds is limited due to high contents of non-starch polysaccharides (NSP), which may reduce nutrient bioavailability (Pedersen et al., 2014). The main NSP in DDGS are insoluble fibers, which tend to hasten the passage of food through the gastrointestinal tract, decreasing nutrient digestibility. Besides, part of the protein in DDGS is associated with fiber, which impairs its digestibility in monogastric animals (Nuez Ortín and Yu, 2009; Chrenková et al., 2012; Silva et al., 2016).

In line with the above, it is interesting to investigate the effects of adding protease with NSP-degrading enzymes to improve nutrient digestibility of DDGS, mainly in terms of protein. Xylanase can hydrolyze xylan fraction of hemicellulose and reduce diet viscosity, facilitating access of endogenous enzymes to nutrients and favoring nitrogen release from fiber fractions. Meanwhile, protease could enhance the release and solubilization of fiber-associated proteins, improving digestibility.

Reports in the literature have shown that replacing corn with up to $180 \mathrm{~g} \mathrm{~kg}^{-1}$ DDGS formulation in diets for dogs may be feasible if associated with xylanase supplementation (Silva et al., 2016). However, higher concentrations of this ingredient associated with other enzymes have not yet been tested in canine diets. Therefore, the objective of this study was to assess the effects of adding $200 \mathrm{~g} \mathrm{~kg}^{-1}$ DDGS formulation to diets supplemented with xylanase and protease for dogs on kibble properties, digestibility, fecal characteristics, and palatability.

\section{Material and Methods}

The experiment was conducted in Curitiba, Paraná State, Brazil $\left(25^{\circ} 25^{\prime} 40^{\prime \prime} \mathrm{S}\right.$ and $\left.49^{\circ} 16^{\prime} 23^{\prime \prime} \mathrm{W}\right)$. The study was conducted according to the local Ethics Committee on Animal Use (CEUA), under case number 055/2015.

Diets were formulated according to the nutritional recommendations of the Association of American Feed Control Officials (AAFCO, 2004) for adult dogs. The differences among them were addition of $200 \mathrm{~g} \mathrm{DDGS} \mathrm{kg}^{-1}$ diet in substitution of corn and chicken viscera meal and inclusions of xylanase and protease enzymes. The ratios of enzyme addition used in the experiment were $0.2 \mathrm{~g} \mathrm{~kg}^{-1}$ for xylanase and $0.5 \mathrm{~g} \mathrm{~kg}^{-1}$ for protease, as determined by the manufacturers.

The experimental diets consisted of: $0 \mathrm{~g} \mathrm{~kg}^{-1}$ DDGS without enzymes (OWE), $0 \mathrm{~g} \mathrm{~kg}^{-1}$ DDGS with xylanase and protease (0XP), $200 \mathrm{~g} \mathrm{~kg}^{-1}$ DDGS without enzymes (200WE), $200 \mathrm{~g} \mathrm{~kg}^{-1}$ DDGS with xylanase (200X), $200 \mathrm{~g} \mathrm{~kg}^{-1}$ DDGS with protease (200P), and $200 \mathrm{~g} \mathrm{~kg}^{-1}$ DDGS with xylanase and protease (200XP) (Tables 1 and 2). All diets were formulated to be isoenergetic.

The xylanase used in the current study $\left(160,000 \mathrm{BXU} \mathrm{g}^{-1}\right.$ xylanase, Econase XT 25, AB Vista, Wiltshire, UK) was produced from Trichoderma reesei strains, and Birch xylan units (BXU) were based on the effect of the enzyme on xylan substrate (extracted from Betula alba) at $50{ }^{\circ} \mathrm{C}$ and $\mathrm{pH} 5.3$. The used protease (Corolase 7089, ABF Ingredients, Peterborough, UK) was produced from Bacillus amyloliquefaciens cultures, with a minimum activity of $850 \mathrm{UHb} \mathrm{g}^{-1}$ and endopeptidase action. One protease unit $(\mathrm{UHb})$ is defined as the enzymatic activity that, under standard conditions $\left(37^{\circ} \mathrm{C}\right.$, defined $\mathrm{pH}, 280 \mathrm{~nm}$ ), catalyzes the release of soluble hemoglobin compounds in trichloroacetic acid, equivalent to $1 \mu \mathrm{mol}$ Tyrosine per minute.

All ingredients were ground in a hammer mill equipped with a 1.2-mm sieve and then mixed and extruded in a double screw extruder (Ferraz, Ribeirão Preto, Brazil). After extrusion, diets were dried in a triple-deck drier $\left(100-110^{\circ} \mathrm{C}\right)$, sprayed with chicken oil, and then cooled. The enzymes were previously dispersed in soybean oil, applied at a proportion of $10 \mathrm{~mL}$ oil per kg diet. The application was carried out in ready-made diets by using a centrifugal mixer at room temperature (approximately $25^{\circ} \mathrm{C}$ ). Diet homogenization with oil lasted $15 \mathrm{~min}$.

Once the diets were produced, they were assessed for density, extruded size, expansion index, hardness, and uniformity. Diet density at the extruder output was calculated from 11 samples of each 
diet. Extruded size was measured using a digital caliper (Paquímetro Absolute, Mitutoyo, São Paulo, Brazil), totaling 10 samples per treatment. The expansion index was calculated as the ratio between the width of extruded material and matrix diameter. For hardness analysis, 50 extruded samples were selected from each diet and analyzed in a durometer (Dr. Schleuniger, Model 5Y tablet tester, Solothurn, Switzerland). Lastly, diet uniformity was assessed by weighing 50 extruded samples from each diet to assess differences among weights.

Six (three males and three females) adult ( $1 \pm 0.1$ years old) non-neutered beagle dogs, with a mean weight of $9.47 \pm 0.71 \mathrm{~kg}$, were used. During digestibility assay, animals were housed in individual masonry stalls $(5 \mathrm{~m}$ long $\times 2 \mathrm{~m}$ wide) .

The experimental diets and DDGS were analyzed for contents of dry matter (DM), crude protein (CP, method 954.01), ash (method 942.05), crude fiber (CF, method 962.10), ether extract after acid hydrolysis (EEAH, method 954.02), starch (adapted from method 996.11; AOAC, 1995), and gross energy (GE) in a calorimetric pump (Parr Instrument Co., Model 1261, Moline, IL, USA). The analysis of neutral detergent fiber, acid detergent fiber, neutral detergent insoluble nitrogen, and acid detergent insoluble nitrogen were performed according to Silva and Queiroz (2002). The fractions of NSP, total dietary fiber, soluble fiber, and insoluble fiber in DDGS and diets were also analyzed according to the method described by Englyst et al. (1982).

Apparent digestibility coefficients (ADC) were determined by the total fecal collection method, as recommended by AAFCO (2004). The digestibility experiment was divided into six periods of ten days each (five adaptation days and five days for stool collection). Animals were fed twice a day (8.00 and $16.00 \mathrm{~h}$ ) to meet their metabolizable energy requirements, as recommended by NRC (2006), and water was supplied ad libitum. Feces were analyzed for $\mathrm{pH}$, ammoniacal nitrogen, fecal score, odor, shortchain fatty acids (SCFA), sialic acid, and chemical composition.

Table 1 - Ingredients of the experimental diets offered to dogs to evaluate inclusion effects of dried distillers grains with solubles (DDGS) and enzymes (xylanase and protease)

\begin{tabular}{|c|c|c|c|c|c|c|}
\hline \multirow{2}{*}{ Ingredient ( $\mathrm{g} \mathrm{kg}^{-1}$, as fed) } & \multicolumn{6}{|c|}{ Diet $^{1}$} \\
\hline & OWE & $0 X P$ & 200WE & $200 X$ & $200 \mathrm{P}$ & $200 X P$ \\
\hline Corn & 600.72 & 600.72 & 471.87 & 471.87 & 471.87 & 471.87 \\
\hline Poultry viscera meal & 300.00 & 300.00 & 190.00 & 190.00 & 190.00 & 190.00 \\
\hline Meat meal & 0 & 0 & 40.00 & 40.00 & 40.00 & 40.00 \\
\hline DDGS & 0 & 0 & 200.00 & 200.00 & 200.00 & 200.00 \\
\hline Poultry viscera oil & 50.00 & 50.00 & 50.00 & 50.00 & 50.00 & 50.00 \\
\hline Liquid hydrolyzate of poultry & 30.00 & 30.00 & 30.00 & 30.00 & 30.00 & 30.00 \\
\hline Potassium chloride & 6.70 & 6.70 & 5.554 & 5.554 & 5.554 & 5.554 \\
\hline Salt & 5.00 & 5.00 & 5.00 & 5.00 & 5.00 & 5.00 \\
\hline Dog premix ${ }^{2}$ & 3.00 & 3.00 & 3.00 & 3.00 & 3.00 & 3.00 \\
\hline Choline chloride & 2.00 & 2.00 & 2.00 & 2.00 & 2.00 & 2.00 \\
\hline Calcium propionate & 2.00 & 2.00 & 2.00 & 2.00 & 2.00 & 2.00 \\
\hline Citric acid & 0.35 & 0.35 & 0.35 & 0.35 & 0.35 & 0.35 \\
\hline BHT & 0.15 & 0.15 & 0.15 & 0.15 & 0.15 & 0.15 \\
\hline BHA & 0.075 & 0.075 & 0.075 & 0.075 & 0.075 & 0.075 \\
\hline Protease & 0 & 0.5 & 0 & 0 & 0.5 & 0.5 \\
\hline Xylanase & 0 & 0.2 & 0 & 0.2 & 0 & 0.2 \\
\hline
\end{tabular}

BHA - butylated hydroxyanisole; BHT - butylated hydroxytoluene.

${ }^{1}$ OWE: $0 \mathrm{~g} \mathrm{~kg}^{-1}$ DDGS without enzymes; 0XP: $0 \mathrm{~g} \mathrm{~kg}^{-1}$ DDGS with xylanase and protease; 200WE: $200 \mathrm{~g} \mathrm{~kg}^{-1}$ DDGS without enzyme; $200 \mathrm{X}$ : $200 \mathrm{~g} \mathrm{~kg}$ DDGS with xylanase; 200P: $200 \mathrm{~g} \mathrm{~kg}^{-1}$ DDGS with protease; 200XP: $200 \mathrm{~g} \mathrm{~kg}^{-1}$ DDGS with xylanase and protease.

2 Enrichment per kg of product: vitamin A (retinol), 20,000 IU; vitamin D3, 2,000 IU; vitamin E (alpha-tocopherol $\alpha$ ), $48 \mathrm{mg}$; vitamin K3, $48 \mathrm{mg}$; vitamin B1, $4 \mathrm{mg}$; vitamin B2, $32 \mathrm{mg}$; pantothenic acid, $16 \mathrm{mg}$; niacin, $56 \mathrm{mg}$; choline, $800 \mathrm{mg}$; Zn as zinc oxide, $150 \mathrm{mg} ; \mathrm{Fe}$ as ferrous sulphate, $100 \mathrm{mg}$; $\mathrm{Cu}$ as copper sulphate, $15 \mathrm{mg}$; I as potassium iodide, $1.5 \mathrm{mg}$; $\mathrm{Mn}$ as manganese oxide, $30 \mathrm{mg}$; Se as sodium selenite, $0.2 \mathrm{mg}$; antioxidant, $240 \mathrm{mg}$. 
Ammonia and $\mathrm{pH}$ were measured in duplicate in fresh feces (within $15 \mathrm{~min}$ after defecation). Fecal pH was measured in $3 \mathrm{~g}$ fresh feces diluted in $30 \mathrm{~mL}$ distilled water using a digital $\mathrm{pH}$ meter (331, Politeste Instrumentos de Teste LTDA, São Paulo, SP, Brazil), while ammonia content was determined according to Brito et al. (2010). Fecal consistency was assessed using a five-point scale, wherein $1=$ pasty and unformed and 5 = well-formed, hard, and dry (Carciofi et al., 2009).

Fecal odor was assessed by 31 volunteers who compared fresh feces of dogs fed the diets containing 200WE and 200XP with the diet containing 0WE. Scores varied from 1 to 3 . A score of 1 was given for an odor better than control, 2 for an odor equal to control, and 3 for an odor worse than control.

To determine SCFA, feces were collected no later than 15 min after defecation. A 10-g sample was homogenized with $30 \mathrm{~mL} 16 \%$ formic acid and stored at $4{ }^{\circ} \mathrm{C}$ for three to five days. These solutions were defrosted and centrifuged at 5,000 rpm in a centrifuge (2K15, Sigma, Osterodeam Hans, Germany) for $15 \mathrm{~min}$. The supernatant was separated and subjected to two other centrifugations. The last supernatant was transferred to an Eppendorf tube for freezing and storage. At the end of all periods, all samples were thawed and centrifuged at 14,000 rpm (Rotanta 460 Robotic, Hettich, Tuttlingen, Germany) for $15 \mathrm{~min}$. Fecal SCFA concentrations were analyzed by gas chromatography (SHIMADZU, model GC-2014, Kyoto, Japan), according to Erwin et al. (1961), using a $30 \mathrm{~m} \times 0.32 \mathrm{~mm}$ glass column (Agilent Technologies, HP-INNOwax-19091N, Santa Clara, USA), and nitrogen as carrier gas at a flow rate of $3.18 \mathrm{~mL} / \mathrm{min}$. The working temperatures were: injection, $200^{\circ} \mathrm{C}$; column, $240^{\circ} \mathrm{C}$ (at a speed of $20^{\circ} \mathrm{C} / \mathrm{min}$ ); and flame ionization detector, $250^{\circ} \mathrm{C}$.

Lyophilized fecal samples (Alpha 1-4 LO plus, Christ, Osterodeam Hans, Germany) were used for sialic acid analysis, according to Jourdian et al. (1971).

At the end of each period, feces were thawed, homogenized, and dried in a forced-ventilation oven at $55^{\circ} \mathrm{C}(320-\mathrm{SE}$, Fanem, São Paulo, Brazil) for $48 \mathrm{~h}$ until constant weight. Once the fecal samples were dried, they were ground in a 1-mm hammer mill (Wiley, Arthur H. Thomas Co., Philadelphia, PA) and stored in plastic bags, previously identified for determination of DM, CP, mineral matter, CF, EEHA, and

Table 2 - Analyzed chemical composition of dried distillers grains with solubles (DDGS) and experimental diets

\begin{tabular}{|c|c|c|c|c|c|c|c|}
\hline \multirow{2}{*}{ Nutrient ( $\mathrm{g} \mathrm{kg}^{-1}$ of DM) } & \multirow{2}{*}{ DDGS } & \multicolumn{6}{|c|}{ Diet $^{1}$} \\
\hline & & OWE & $0 X P$ & 200WE & $200 X$ & $200 \mathrm{P}$ & $200 \times P$ \\
\hline Dry matter (DM) & 952.3 & 918.2 & 925.6 & 948.5 & 953.1 & 951.1 & 948.2 \\
\hline Crude protein & 254.1 & 225.3 & 227.7 & 242.6 & 244.2 & 243.2 & 240.4 \\
\hline NDIN & 15.2 & 5.0 & 6.8 & 8.3 & 10.2 & 10.2 & 12.8 \\
\hline ADIN & 2.4 & 0.5 & 0.6 & 2.2 & 2.3 & 1.2 & 1.2 \\
\hline EEAH & 105.6 & 153.4 & 148.3 & 146.9 & 150.4 & 149.3 & 145.7 \\
\hline Mineral matter & 70.8 & 80.2 & 80.5 & 67.2 & 64.2 & 62.4 & 64.4 \\
\hline Crude fiber & 114.4 & 12.9 & 11.4 & 23.8 & 22.9 & 23.7 & 21.4 \\
\hline Neutral detergent fiber & 605.3 & 103.7 & 113.3 & 203.5 & 204.2 & 212.9 & 200.9 \\
\hline Acid detergent fiber & 150.5 & 13.2 & 13.2 & 35.3 & 36.5 & 38.3 & 34.8 \\
\hline Total dietary fiber ${ }^{2}$ & 323.0 & 49.0 & 51.0 & 1100.0 & 114.0 & 116.0 & 116.0 \\
\hline Insoluble fiber & 302.0 & 41.0 & 42.0 & 98.0 & 103.0 & 99.0 & 99.0 \\
\hline Soluble fiber & 21.0 & 7.0 & 9.0 & 12.0 & 11.0 & 17.0 & 17.0 \\
\hline Digestible starch & 83.9 & - & - & - & - & - & - \\
\hline Resistant starch & 44.2 & - & - & - & - & - & - \\
\hline Total starch & 128.1 & - & - & - & - & - & - \\
\hline Non-nitrogen extract & 407.4 & 446.4 & 457.7 & 467.9 & 471.3 & 472.5 & 476.3 \\
\hline Metabolizable energy $^{3}\left(\mathrm{MJ} \mathrm{kg}^{-1}\right)$ & 15.68 & 15.30 & 15.32 & 15.64 & 15.84 & 15.80 & 15.69 \\
\hline
\end{tabular}

NDIN - neutral detergent insoluble nitrogen; ADIN - acid detergent insoluble nitrogen; EEHA - ether extract after acid hydrolysis.

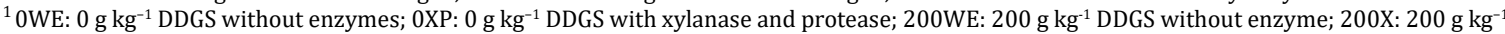

DDGS with xylanase; 200P: $200 \mathrm{~g} \mathrm{~kg}^{-1}$ DDGS with protease; $200 \mathrm{XP}: 200 \mathrm{~g} \mathrm{~kg}^{-1}$ DDGS with xylanase and protease.

${ }^{2}$ Obtained by the sum of the soluble and insoluble portions.

${ }^{3}$ Estimated according to NRC (2006). 
GE, following the above-described methods. Based on laboratory results, the ADC of the variables were calculated using the following equation:

$$
\mathrm{ADC}=(\mathrm{g} \text { of nutrient intake }-\mathrm{g} \text { of nutrient excretion }) / \mathrm{g} \text { of nutrient intake }
$$

Metabolizable energy (ME) was estimated according to AAFCO (2004), as follows: $\mathrm{ME}\left(\mathrm{kJ} \mathrm{g}^{-1}\right)=\left\{\mathrm{kJ} \mathrm{g}^{-1}\right.$ of GE intake - $\mathrm{kJ} \mathrm{g}^{-1}$ of fecal GE - [(g of CP intake - $\mathrm{g}$ of fecal CP) $\left.\left.\times 5.23 \mathrm{~kJ} \mathrm{~g}^{-1}\right]\right\} / \mathrm{g}$ of food intake

The experimental design was a $6 \times 6$ Latin square with six treatments and six periods. Residual normality was analyzed by the Shapiro-Wilk test $(\mathrm{P}>0.05)$. When this assumption was met, data were subjected to the statistical package SAS (Statistical Analysis System, version 8). Data on kibble properties were subjected to mean comparison by the Student's t test.

Digestibility and fecal characteristics were assessed by the following orthogonal contrasts $(\mathrm{P}<0.05)$ : (OWE; 0XP) vs. (200WE; 200X; 200P; 200XP): diets without DDGS vs. diets including $200 \mathrm{~g} \mathrm{~kg}^{-1}$ DDGS; OWE vs. OXP: diet without DDGS and enzymes vs. diet without DDGS and with xylanase and protease; 200WE vs. (200X; 200P; 200XP): diet containing $200 \mathrm{~g} \mathrm{~kg}^{-1}$ DDGS without enzymes vs. diets containing $200 \mathrm{~g} \mathrm{~kg}^{-1}$ DDGS with the enzymes xylanase and protease, isolated and associated; (200X; 200P) vs. 200XP: diets containing $200 \mathrm{~g} \mathrm{~kg}^{-1}$ DDGS with isolated enzymes vs. diet containing $200 \mathrm{~g} \mathrm{~kg}^{-1}$ DDGS with associated enzymes; $200 \mathrm{X}$ vs. $200 \mathrm{P}$ : diet containing $200 \mathrm{~g} \mathrm{~kg}^{-1}$ DDGS with xylanase vs. diet containing $200 \mathrm{~g} \mathrm{~kg}^{-1}$ DDGS with protease.

Data on fecal characteristics that failed to meet the normality assumption were subjected to the Kruskal-Wallis test at $5 \%$ probability. P-values lower than 0.05 were considered significant and between 0.05 and 0.1 , as trends.

Variables were analyzed according to the following mathematical model:

$$
\text { Yij }=\mu+\beta i+\varepsilon i j,
$$

in which, Yij = observation $j$ of experimental unit subjected to treatments $i, \mu=$ general constant, $\beta i=$ effects of adding DDGS to diets supplemented with xylanase and protease, and $\varepsilon \mathrm{ij}=$ random error associated to each observation.

Another assay (two-day evaluation) was carried out using sixteen (eight males and eight females) adult $(1 \pm 0.1$ years old) beagle dogs, with a mean weight of $9.47 \pm 0.71 \mathrm{~kg}$. The assay was composed of two tests (first choice and intake ratio), which were composed of 32 observations. In this experiment, the following diets were compared: 0WE vs. 200WE and 0XP vs. 200XP.

Once a day, each dog received two pots, each of them containing one of the assessed diets with $30 \%$ more ME than the recommended by NRC (2006). As soon as one of the diets was completely consumed, both pots were removed, and leftovers quantified. On the second day, the position of feeders was changed to avoid conditioned feeding behavior.

The first choice was defined as the first pot that the dog approached during simultaneous feed supply. The intake ratio was calculated by the following equation:

$$
\text { Intake ratio }\left(\mathrm{g} \mathrm{kg}^{-1}\right)=[\mathrm{g} \text { ingested from } \operatorname{diet} \mathrm{A} \text { or } \mathrm{B} / \text { total } \mathrm{g} \text { consumed }(\mathrm{A}+\mathrm{B})] \times 100
$$

The experimental design was completely randomized. Sixteen animals were used, totaling 32 replications per test ( 16 dogs $\times$ two days). The first-choice data were subjected to a chi-square test and intake ratio to the Student's t test, both at a significance level of 0.05 .

\section{Results}

No difference $(\mathrm{P}>0.05)$ was observed among the tested diets regarding density, size, expansion index, hardness, and uniformity (Table 3).

Xylanase and protease addition in diets had no effect on ADC of nutrients and ME $(\mathrm{P}>0.05)$. However, a reduction $(\mathrm{P}<0.05$; Table 4$)$ was observed in ADC of DM, EEAH, GE, and organic matter (OM) with DDGS addition. 
Regarding fecal characteristics, $\mathrm{pH}$ reduced with DDGS addition $(\mathrm{P}<0.05$; Table 4$)$ and was similar for all diets containing the ingredient. However, no change was observed for DM after DDGS or enzyme addition ( $P>0.05$; Table 4). Addition of DDGS increased the total production of SCFA and acetic and propionic acids $(\mathrm{P}<0.05)$, without altering butyric, isobutyric, valeric, and isovaleric acid production (Table 4). Animals fed diets containing DDGS (200WE and 200XP) had more fetid feces ( $\mathrm{P}<0.04$; Table 5). However, no change was observed for sialic acid, ammoniacal nitrogen, and fecal score ( $P>0.05$; Table 5 ), regardless of the treatment.

No change was observed in the first-choice test for any of the assessed diets ( $P>0.05$; Table 6). Regarding intake ratio, no difference was observed when comparing diets $0 \mathrm{WE}$ and 200WE $(\mathrm{P}>0.05$; Table 6). However, animals ingested a higher amount of diet 0XP compared with 200XP $(\mathrm{P}<0.05$; Table 6).

Table 3 - Mean values of density, size, expansion index, hardness, and uniformity of diets offered to dogs to evaluate inclusion effects of dried distillers grains with solubles (DDGS) and enzymes (xylanase and protease)

\begin{tabular}{lcccc}
\hline & OWE & 200WE & MSE & P \\
\hline Density (gL-1) & 415.50 & 420.14 & 0.39 & 0.448 \\
Size (mm) & 0.96 & 0.78 & $0.96^{-3}$ & 0.172 \\
Expansion index & 0.213 & 0.17 & $1.95^{-3}$ & 0.172 \\
Hardness (N) & 103.12 & 64.06 & 2.94 & 0.473 \\
Uniformity (g) & 0.26 & 0.24 & $2.21^{-3}$ & 0.464 \\
\hline
\end{tabular}

MSE - mean standard error.

0WE: diet containing $0 \mathrm{~g} \mathrm{~kg}^{-1}$ DDGS without enzymes; 200WE: diet containing $200 \mathrm{~g} \mathrm{~kg}^{-1}$ DDGS without enzymes.

Table 4 - Effect of addition of dried distillers grains with solubles (DDGS) to dog diets supplemented with xylanase and protease on apparent digestibility coefficient (ADC) and metabolizable energy (ME, $\mathrm{MJ} \mathrm{kg}^{-1}$ ) of diets and fecal characteristics of dogs

\begin{tabular}{|c|c|c|c|c|c|c|c|c|c|c|c|c|}
\hline & \multicolumn{6}{|c|}{$\operatorname{Diet}^{1}$} & \multirow{2}{*}{ MSE } & \multicolumn{5}{|c|}{ Contrast $^{2}$} \\
\hline & OWE & 0XP & 200WE & $200 X$ & $200 \mathrm{P}$ & $200 X P$ & & A & $\mathrm{B}$ & $\mathrm{C}$ & $\mathrm{D}$ & $\mathrm{E}$ \\
\hline \multicolumn{13}{|c|}{ Apparent digestibility coefficient ( $\mathrm{g} \mathrm{kg}^{-1}$ of dry matter) } \\
\hline Dry matter (DM) & 0.839 & 0.838 & 0.768 & 0.767 & 0.760 & 0.742 & 0.86 & $<0.001$ & 1.000 & 0.993 & 0.933 & 0.999 \\
\hline EEAH & 0.925 & 0.927 & 0.888 & 0.898 & 0.883 & 0.864 & 0.48 & $<0.001$ & 1.000 & 0.986 & 0.173 & 0.813 \\
\hline Crude protein & 0.842 & 0.848 & 0.807 & 0.819 & 0.798 & 0.776 & 0.66 & 0.050 & 0.999 & 0.996 & 0.624 & 0.946 \\
\hline Gross energy & 0.884 & 0.882 & 0.809 & 0.821 & 0.806 & 0.787 & 0.86 & $<0.001$ & 1.000 & 0.999 & 0.640 & 0.973 \\
\hline Organic matter & 0.876 & 0.878 & 0.790 & 0.790 & 0.784 & 0.773 & 0.89 & $<0.001$ & 1.000 & 0.998 & 0.978 & 0.999 \\
\hline Metabolizable energy $\left(\mathrm{MJ} \mathrm{kg}{ }^{-1}\right)$ & 17.14 & 17.24 & 16.81 & 16.82 & 16.36 & 16.14 & 26.31 & 0.071 & 0.999 & 0.821 & 0.719 & 0.812 \\
\hline \multicolumn{13}{|l|}{ Fecal characteristics } \\
\hline DMf $\left(\mathrm{g} \mathrm{kg}^{-1}\right)$ & 407.5 & 384.9 & 366.2 & 347.6 & 359.9 & 370.7 & 0.879 & 0.383 & 0.969 & 0.999 & 0.983 & 0.998 \\
\hline $\mathrm{pH}$ & 7.07 & 7.19 & 6.39 & 6.51 & 6.59 & 6.48 & 0.076 & 0.002 & 0.994 & 0.975 & 0.999 & 0.999 \\
\hline \multicolumn{13}{|c|}{ Short-chain fatty acid (SCFA; mmol g-1 faecal DM) } \\
\hline Acetic & 57.68 & 61.23 & 83.52 & 75.97 & 92.43 & 87.41 & 0.027 & 0.005 & 0.999 & 0.999 & 0.999 & 0.598 \\
\hline Propionic & 26.87 & 31.16 & 44.76 & 43.92 & 51.83 & 45.77 & 0.105 & 0.002 & 0.984 & 0.997 & 0.999 & 0.816 \\
\hline Butyric & 10.52 & 9.634 & 11.38 & 9.78 & 12.37 & 11.49 & 5.514 & 0.936 & 0.998 & 1.000 & 0.999 & 0.819 \\
\hline Valeric & 0.539 & 0.421 & 0.492 & 0.587 & 0.589 & 0.476 & 3.25 & 0.961 & 0.891 & 0.986 & 0.850 & 1.000 \\
\hline Isobutyric & 2.09 & 1.909 & 1.081 & 2.200 & 1.918 & 1.749 & 0.498 & 0.994 & 0.979 & 0.975 & 0.721 & 0.873 \\
\hline Isovaleric & 2.831 & 2.429 & 2.454 & 2.911 & 2.646 & 2.362 & 0.069 & 1.000 & 0.882 & 0.989 & 0.779 & 0.978 \\
\hline Total SCFA ${ }^{3}$ & 100.53 & 106.79 & 144.42 & 135.37 & 161.79 & 149.26 & 2.0121 & 0.007 & 0.999 & 0.999 & 1.000 & 0.699 \\
\hline
\end{tabular}

EEAH - ether extract after acid hydrolysis; DMf - fecal dry matter; MSE - mean standard error.

${ }^{1}$ OWE: $0 \mathrm{~g} \mathrm{~kg}^{-1}$ DDGS without enzymes; 0XP: $0 \mathrm{~g} \mathrm{~kg}^{-1}$ DDGS with xylanase and protease; $200 \mathrm{WE}: 200 \mathrm{~g} \mathrm{~kg}^{-1} \mathrm{DDGS}_{\text {without enzyme; } 200 \mathrm{X}: 200 \mathrm{~g} \mathrm{~kg}}{ }^{-1}$ DDGS with xylanase; 200P: $200 \mathrm{~g} \mathrm{~kg}^{-1}$ DDGS with protease; 200XP: $200 \mathrm{~g} \mathrm{~kg}^{-1}$ DDGS with xylanase and protease.

2 A: (0WE; 0XP) × (200WE; 200X; 200P; 200XP); B: 0WE × 0XP; C: 200WE × (200X; 200P; 200XP); D: (200X; 200P) × 200XP; E: 200X × 200P.

${ }^{3}$ Calculated as the sum of the SCFA assessed in the experiment. 
Table 5 - Medians of sialic acid (mg), ammoniacal nitrogen $\left(\mathrm{g} \mathrm{kg}^{-1}\right)$, fecal score, and fecal odor of dogs fed diets to evaluate inclusion effects of dried distillers grains with solubles (DDGS) and enzymes (xylanase and protease)

\begin{tabular}{lccccccc}
\hline & $0 \mathrm{WE}$ & $0 \mathrm{XP}$ & $200 \mathrm{WE}$ & $200 \mathrm{X}$ & $200 \mathrm{P}$ & $200 \mathrm{XP}$ & $\mathrm{P}$ \\
\hline Sialic acid & 0.9941 & 0.8618 & 1.0383 & 1.0248 & 0.9750 & 1.0693 & 0.456 \\
Fecal $\mathrm{NH}_{3}$ & 1.003 & 0.852 & 0.722 & 0.729 & 0.92 & 0.605 & 0.153 \\
Fecal score & 4 & 4 & 4 & 4 & 4 & 4 & 0.322 \\
Fecal odor & $2 \mathrm{a}$ & - & $3 \mathrm{~b}$ & - & - & $3 \mathrm{~b}$ & $<0.001$ \\
\hline
\end{tabular}

OWE: $0 \mathrm{~g} \mathrm{~kg}^{-1}$ DDGS without enzymes; 0XP: $0 \mathrm{~g} \mathrm{~kg}^{-1}$ DDGS with xylanase and protease; 200WE: $200 \mathrm{~g} \mathrm{~kg}^{-1} \mathrm{DDGS}_{\text {without enzyme; } 200 \mathrm{X}: 200 \mathrm{~g} \mathrm{~kg}}{ }^{-1}$ DDGS with xylanase; 200P: $200 \mathrm{~g} \mathrm{~kg}^{-1}$ DDGS with protease; 200XP: $200 \mathrm{~g} \mathrm{~kg}^{-1}$ DDGS with xylanase and protease.

a,b,c - Different letters indicate difference by the Kruskal-Wallis test $(\mathrm{P}<0.05)$.

Table 6 - Number of visits to diet feeder A and intake ratio (IR \pm standard error) for dogs

\begin{tabular}{lcc}
\hline Diet A vs. B & $\mathrm{N}^{1}$ & ${\text { IR } \operatorname{diet} \mathrm{A}^{2}}^{2}$ \\
\hline 0WE vs. 200WE & 13 & $0.48 \pm 0.05$ \\
0XP vs. 200XP & 12 & $0.61 \pm 0.049^{*}$ \\
\hline
\end{tabular}

OWE: $0 \mathrm{~g} \mathrm{~kg}^{-1}$ DDGS without enzymes; 0XP: $0 \mathrm{~g} \mathrm{~kg}^{-1}$ DDGS with xylanase and protease; 200WE: $200 \mathrm{~g} \mathrm{~kg}^{-1} \mathrm{DDGS}_{\text {without enzyme; } 200 X P: 200 \mathrm{~g} \mathrm{~kg}-1}$ DDGS with xylanase and protease.

* Value of $\mathrm{P}<0.05$ for the number of visits for diet $\mathrm{A}$ by the chi-square test and Student's t test for intake ratio.

${ }^{1}$ Number of visits to the feeder $B$ is obtained by $32-n$.

${ }^{2} \mathrm{IR}=\mathrm{g}$ ingested from $\operatorname{diet} \mathrm{A}$ or $\mathrm{B} / \mathrm{g}$ total provided $(\mathrm{A}+\mathrm{B})$; IR of diet B is obtained by $1-$ IR of $\operatorname{diet} \mathrm{A}$.

\section{Discussion}

Under the conditions of this experiment, the addition of $200 \mathrm{~g} \mathrm{~kg}^{-1}$ DDGS did not alter the density, expansion index, hardness, size, and uniformity of kibbles.

Reductions in the ADC of DM, OM, EEAH, CP, GE, and ME caused by DDGS addition have also been reported by Silva et al. (2016), who evaluated dogs fed increasing DDGS levels $\left(0,60,120\right.$, and $\left.180 \mathrm{~g} \mathrm{~kg}^{-1}\right)$. These authors correlated the declines with increasing NSP in the diets. Other experiments with dogs also showed a reduction in ADC of DM with DDGS addition (Allen et al., 1981; Corbin et al., 1984).

Regarding protein digestibility, Corbin et al. (1984) reported no reduction in protein absorption or retention after adding $157 \mathrm{~g} \mathrm{~kg}^{-1}$ DDGS. In a study conducted with increasing DDGS proportions $(0$, 150, and $260 \mathrm{~g} \mathrm{~kg}^{-1}$ ) in diets for adult dogs, Allen et al. (1981) also observed no reduction in protein digestibility. These data are in accordance with our results, in which there was no decrease in the ADC of CP with addition of $200 \mathrm{~g} \mathrm{~kg}^{-1}$ DDGS. In the study of Allen et al. (1981), ME reduced with DDGS (260 $\left.\mathrm{g} \mathrm{kg}^{-1} \mathrm{DM}\right)$ inclusion, as observed in our study.

The addition of enzymes had no effect on nutrient digestibility or ME of the diets, unlike the findings in the literature on dogs. For instance, Silva et al. (2016) tested increasing DDGS levels and xylanase supplementation and observed increases in the ADC of CP, DM, and OM when the enzyme was added; they also noted that the ADC of CP was similar between treatments with and without the inclusion of the ingredient (Silva et al., 2016). Such a difference in results could be due to the enzyme concentration, as in our study, the concentration was lower $\left(0.2 \mathrm{~g} \mathrm{~kg}^{-1}\right)$ than that used by Silva et al. (2016) $\left(0.5 \mathrm{~g} \mathrm{~kg}^{-1}\right)$. Therefore, the relationship between exogenous enzyme concentration and amount of substrate may not have been enough to influence the ADC values.

Several factors can influence the efficacy of exogenous enzymes such as enzymatic source, ingredient processing and variability, interaction with other dietary components, and animal intrinsic factors (Bedford and Schulze, 1998). The great variability of DDGS sources must also be considered since better-quality materials have less substrate and, hence, a minor enzymatic effect. This can be observed by comparing our findings with those of Barekatain et al. (2013), in which a higher xylan concentration enhanced the enzymatic effect, corroborating the hypothesis of the low enzyme concentration used in our study. The content of xylose found in the DDGS source used in the experiment of Silva et al. 
(2016) was $109 \mathrm{~g} \mathrm{~kg}^{-1}$, i.e., the same as that found in the source used in our study. Thus, substrate concentration in the diets used in our study was higher than that tested by these authors, given the higher DDGS inclusion content. Therefore, the reduction of enzymatic inclusion was enough to prevent the enzymatic effect.

In the literature, there is a hypothesis on the action of protease in diets containing corn DDGS, which consists of the hydrolysis of corn xylanase inhibitors such as Triticum aestivum xylanase inhibitor (TAXI) and xylanase-inhibiting proteins (XIP) (Pedersen et al., 2015). In our study, protease might have acted on such protease inhibitors; however, as xylanase concentration was insufficient, a synergistic effect of both enzymes could not be detected.

Regarding the association between xylanase and protease, Pedersen et al. (2015) found an increase in in vitro protein solubility of corn DDGS samples. In a study with broilers, protease addition increased the digestibility of amino acids and ME in diets containing DDGS with xylanase and amylase (Romero et al., 2013). These results highlight the need to test other enzymes and different xylanase and protease concentrations to improve the ADC of DDGS.

In our study, DDGS addition reduced $(\mathrm{P}<0.05)$ fecal $\mathrm{pH}$, indicating a possible prebiotic effect. Silva et al. (2016) also observed a pH reduction by incorporating $180 \mathrm{~g} \mathrm{~kg}^{-1}$ DDGS into diets for dogs and attributed this to an increase in total SCFA production (Kawauchi et al., 2011). Likewise, Lopez et al. (1999) evaluated diets for rats containing AX (one of the main NSP of DDGS) and observed a reduction in fecal pH from 7.0 to 6.0; they assigned this effect to SCFA accumulation in animal intestines, as observed in our study. Lu et al. (2000), also studying rats fed diets containing AX, reported a reduction in intestinal $\mathrm{pH}$. This $\mathrm{pH}$ reduction due to increased production of SCFA is seen as beneficial to animals since at $\mathrm{pH}$ below 7.0, it is believed to decrease the absorption of tumor promoters such as ammonia (Visek, 1978).

Addition of DDGS increased total SCFA production, pointing to changes in the microbial fermentation profile. Belobrajdic et al. (2012) and Calabrò et al. (2013) also reported this when analyzing diets containing $\mathrm{AX}$, associating such effect with a higher concentration of this substrate found in animal intestines. Among the SCFA tested in our study, acetic and propionic acids showed an increased production, just as observed by Hopkins et al. (2003) in an experiment performed with in vitro AX fermentation. This may be indicative of the prebiotic effect of DDGS, although a potential selective growth of beneficial microbial species requires further studies.

No changes in fecal score, ammoniacal nitrogen, and DM contents were observed with DDGS addition, as reported by Silva et al. (2016). Both DM and fecal score were within regular levels for the species. Feces from animals fed diets containing DDGS were more fetid than those from animals that did not receive this ingredient. This may be due to a higher SCFA content found in diets containing such ingredient (Yamakoshi et al., 2001). Sialic acid increase is indicative of aggression to the intestinal mucosa (Pirgozliev et al., 2005), and it was not altered by the addition of fiber from DDGS to the diets. This result indicates that DDGS was not deleterious to the intestinal mucosa. A similar result was observed by Sabchuk et al. (2017), who assessed different fiber levels in diets for dogs and observed no changes in the content of sialic acid in feces of animals.

Regarding palatability, the addition of DDGS with or without enzyme supplementation did not interfere with the first choice of animals, unlike the results found in the literature. In an experiment conducted by Silva et al. (2016), dogs had a diet containing $180 \mathrm{~g} \mathrm{~kg}^{-1}$ DDGS as their first choice. According to the intake ratio of diets without enzymes, the addition of $200 \mathrm{~g} \mathrm{~kg}^{-1}$ DDGS did not cause differences in palatability between the diets. This result differs from those found in the literature also for dogs (Corbin et al., 1984; Silva et al., 2016). For Silva et al. (2016), a diet containing $180 \mathrm{~g} \mathrm{~kg}^{-1}$ DDGS was more palatable to dogs than that without the addition of this ingredient.

When comparing 0XP and 200XP by intake ratio, animal preference was higher for the diet without DDGS inclusion. Such a preference cannot be attributed to a specific cause, since palatability is extremely complex and influenced by several factors. Among the aspects influencing this attribute are food organoleptic characteristics, social imprinting, and neophilic or neophobic behavior of animals 
(Félix et al., 2010). Thus, other studies are still needed to better understand interactions among DDGS inclusion, enzymes, and palatability in dogs.

\section{Conclusions}

Adding $200 \mathrm{~g} \mathrm{~kg}^{-1}$ DDGS to diet for dogs reduces the digestibility of dry matter, ether extract after acid hydrolysis, gross energy, and organic matter compared with a diet with corn and poultry viscera meal and does not change kibble properties. Despite the reduction, DDGS should be included in low-cost diets for dogs, given that digestibility remains within acceptable limits for some pet food categories. Inclusion of DDGS has a potential prebiotic effect and changes the short-chain fatty acid profile. The concentrations of xylanase and protease enzymes added to diets, jointly or separately, does not improve apparent digestibility coefficients of nutrients, metabolizable energy, or fecal characteristics of dogs.

\section{Conflict of Interest}

The authors declare no conflict of interest.

\section{Author Contributions}

Conceptualization: L.W. Risolia, A.P. Félix, A. Maiorka and S.G. Oliveira. Investigation: L.W. Risolia, T.T. Sabchuk, F.Y. Murakami, A. Maiorka and S.G. Oliveira. Methodology: T.T. Sabchuk and A.P. Félix. Writingoriginal draft: L.W. Risolia and S.G. Oliveira. Writing-review \& editing: S.G. Oliveira.

\section{References}

Allen, S. E.; Fahey Jr., G. C.; Corbin, J. E.; Pugh, J. L. and Franklin, R. A. 1981. Evaluation of byproduct feedstuffs as dietary ingredients for dogs. Journal of Animal Science 53:1538-1544. https://doi.org/10.2527/jas1982.5361538x

AAFCO - Association of American Feed Control Officials. 2004. Dog and cat nutrient profiles. Official Publications of the Association of American Feed Control Officials Incorporated. AAFCO, Oxford, IN, USA.

AOAC - Association of Official Analytical Chemists. 1995. Official methods of analysis. 16th ed. AOAC, Arlington, VA.

Barekatain, M. R.; Antipatis, C.; Choct, M. and Iji, P. A. 2013. Interaction between protease and xylanase in broiler chicken diets containing sorghum distillers' dried grains with solubles. Animal Feed Science and Technology 182:71-81. https://doi.org/10.1016/j.anifeedsci.2013.04.002

Bedford, M. R. and Schulze, H. 1998. Exogenous enzymes for pigs and poultry. Nutrition Research Reviews 11:91-114. https://doi.org/10.1079/NRR19980007

Belobrajdic, D. P.; Bird, A. R.; Conlon, M. A.; Williams, B. A.; Kang, S.; McSweeney, C. S.; Zhang, D.; Bryden, W. L.; Gidley, M. J. and Topping, D. L. 2012. An arabinoxylan-rich fraction from wheat enhances caecal fermentation and protects colonocyte DNA against diet-induced damage in pigs. British Journal of Nutrition 107:1274-1282. https://doi.org/10.1017/ S0007114511004338

Brito, C. B. M.; Félix, A. P.; Jesus, R. M.; França, M. I.; Oliveira, S. G.; Krabbe, E. L. and Maiorka, A. 2010. Digestibility and palatability of dog foods containing different moisture levels, and the inclusion of a mould inhibitor. Animal Feed Science and Technology 159:150-155.

Calabrò, S.; Carciofi, A. C.; Musco, N.; Tudisco, R.; Gomes, M. O. S. and Cutrignelli, M. I. 2013. Fermentation characteristics of several carbohydrate sources for dog diets using the in vitro gas production technique. Italian Journal of Animal Science 12:e4. https://doi.org/10.4081/ijas.2013.e4

Carciofi, A. C.; De-Oliveira, L. D.; Valério, A. G.; Borges, L. L.; Carvalho, F. M.; Brunetto, M. A. and Vasconcellos, R. S. 2009. Comparison of micronized whole soybeans to common protein sources in dry dog and cat diets. Animal Feed Science and Technology 151:251-260. https://doi.org/10.1016/j.anifeedsci.2009.01.002

Chrenková, M.; Čerešňáková, Z.; Formelová, Z.; Poláčiková, M.; Mlyneková, Z. and Flak, P. 2012. Chemical and nutritional characteristics of different types of DDGS for ruminants. Journal of Animal and Feed Sciences 21:425-435. https://doi. org/10.22358/jafs/66108/2012

Corbin, J.; Fahey, G. C. and Pugh, J. L. 1984. Distillers dried grains with solubles for growing puppies. p.29-34. In: Distillers Feed Conference. 
Englyst, H.; Wiggins, H. S. and Cummings, J. H. 1982. Determination of the non-starch polysaccharides in plant foods by gas-liquid chromatography of constituent sugars as alditol acetates. Analyst 107:307-318. https://doi.org/10.1039/ an9820700307

Erwin, E. S.; Marco, G. J. and Emery, E. M. 1961. Volatile fatty acid analyses of blood and rumen fluid by gas chromatography. Journal of Dairy Science 44:1768-1771. https://doi.org/10.3168/jds.S0022-0302(61)89956-6

Félix, A. P.; Oliveira, S. G. and Maiorka, A. 2010. Fatores que interferem no consumo de alimentos em cães e gatos. p.162-199. In: Consumo e preferência alimentar dos animais domésticos. Vieira S. L., ed. Phytobiotics, Londrina.

Hopkins, M. J.; Englyst, H. N.; Macfarlane, S.; Furrie, E.; Macfarlane, G. T. and McBain, A. J. 2003. Degradation of cross-linked and non-cross-linked arabinoxylans by the intestinal microbiota in children. Applied and Environmental Microbiology 69:6354-6360. https://doi.org/10.1128/aem.69.11.6354-6360.2003

Jourdian, G. W.; Dean, L. and Roseman, S. 1971. The sialic acids XI. A periodate-resorcinol method for the quantitative estimation of free sialic acids and their glycosides. Journal of Biological Chemistry 246:430-435.

Kawauchi, I. M.; Sakomura, N. K.; Vasconcellos, R. S.; De-Oliveira, L. D.; Gomes, M. O. S.; Loureiro, B. A. and Carciofi, A. C. 2011. Digestibility and metabolizable energy of maize gluten feed for dogs as measured by two different techniques. Animal Feed Science and Technology 169:96-103. https://doi.org/10.1016/j.anifeedsci.2011.05.005

Lopez, H. W.; Levrat, M. A.; Guy, C.; Messager, A.; Demigné, C. and Rémésy, C. 1999. Effects of soluble corn bran arabinoxylans on cecal digestion, lipid metabolism, and mineral balance $(\mathrm{Ca}, \mathrm{Mg}$ ) in rats. Journal of Nutritional Biochemistry 10:500-509. https://doi.org/10.1016/S0955-2863(99)00036-4

Lu, Z. X.; Gibson, P. R.; Muir, J. G.; Fielding, M. and O’Dea, K. 2000. Arabinoxylan fiber from a by-product of wheat flour processing behaves physiologically like a soluble, fermentable fiber in the large bowel of rats. Journal of Nutrition 130:1984-1990. https://doi.org/10.1093/jn/130.8.1984

NRC - National Research Council. 2006. Nutrient requirements of dogs and cats. National Academy Press, Washington, DC, USA.

Nuez Ortín, W. G. and Yu, P. 2009. Nutrient variation and availability of wheat DDGS, corn DDGS and blend DDGS from bioethanol plants. Journal of the Science of Food and Agriculture 89:1754-1761. https://doi.org/10.1002/jsfa.3652

Pedersen, M. B.; Dalsgaard, S.; Knudsen, K. E. B.; Yu, S. and Laerke, H. N. 2014. Compositional profile and variation of distillers dried grains with solubles from various origins with focus on non-starch polysaccharides. Animal Feed Science and Technology 197:130-141. https://doi.org/10.1016/j.anifeedsci.2014.07.011

Pedersen, M. B.; Dalsgaard, S.; Arent, S.; Lorentsen, R.; Knudsen, K. E. B.; Yu, S. and Laerke, H. N. 2015. Xylanase and protease increase solubilization of non-starch polysaccharides and nutrient release of corn- and wheat distillers dried grains with solubles. Biochemical Engineering Journal 98:99-106. https://doi.org/10.1016/j.bej.2015.02.036

Pirgozliev, V.; Shanmugavelu, S. and Acamovic, T. 2005. Effect of the method of drying on the concentration of sialic acid in poultry excreta. p.536-538. In: Proceedings of the 15th European Symposium on Poultry Nutrition, Balatonfüred, Hungary. World's Poultry Science Association, Beekbergen, the Netherlands.

Romero, L. F.; Parsons, C. M.; Utterback, P. L.; Plumstead, P. W. and Ravindran, V. 2013. Comparative effects of dietary carbohydrates without or with protease on the ileal digestibility of energy and amino acids and AME $\mathrm{n}_{\mathrm{n}}$ in young broilers. Animal Feed Science and Technology 181:35-44. https://doi.org/10.1016/j.anifeedsci.2013.02.001

Sabchuk, T. T.; Lowndes, F. G.; Scheraiber, M.; Silva, L. P.; Félix, A. P.; Maiorka, A. and Oliveira, S. G. 2017. Effect of soya hulls on diet digestibility, palatability, and intestinal gas production in dogs. Animal Feed Science and Technology 225:134-142. https://doi.org/10.1016/j.anifeedsci.2017.01.011

Silva, D. J. and Queiroz, A. C. 2002. Análises de alimentos: métodos químicos e biológicos. UFV, Viçosa, MG. 235p.

Silva, J. R.; Sabchuk, T. T.; Lima, D. C.; Félix, A. P.; Maiorka, A. and Oliveira, S. G. 2016. Use of distillers dried grains with solubles (DDGS), with and without xylanase, in dog food. Animal Feed Science and Technology 220:136-142. https://doi.org/10.1016/j.anifeedsci.2016.08.001

Spiehs, M. J.; Whitney, M. H. and Shurson, G. C. 2002. Nutrient database for distiller's dried grains with solubles produced from new ethanol plants in Minnesota and South Dakota. Journal of Animal Science 80:2639-2645.

Visek, W. J. 1978. Diet and cell growth modulation by ammonia. American Journal of Clinical Nutrition 31:S216-S220. https://doi.org/10.1093/ajcn/31.10.S216

Yamakoshi, J.; Tokutake, S.; Kikuchi, M.; Kubota, Y.; Konishi, H. and Mitsuoka, T. 2001. Effect of proanthocyanidin-rich extract from grape seeds on human fecal flora and fecal odor. Microbial Ecology in Health and Disease 13:25-31. https://doi.org/10.1080/089106001750071672

Widyaratne, G. P. and Zijlstra, R. T. 2007. Nutritional value of wheat and corn distiller's dried grain with solubles: Digestibility and digestible contents of energy, amino acids and phosphorus, nutrient excretion and growth performance of grower-finisher pigs. Canadian Journal of Animal Science 87:103-114. https://doi.org/10.4141/A05-070 